\title{
Early Proliferation of Bone Marrow Mononuclear Cells on Collagen Membrane, Bone Graft and Tooth Cementum
}

\author{
Proliferación Temprana de Células Mononucleares de Médula Ósea \\ sobre Membrana de Colágeno, Injerto Óseo y Cemento Dentario
}

\author{
*,***ébora Milagres; ${ }^{* *}$ Carlos R. Rueff-Barroso; ${ }^{* * *}$ Simone N. Carvalho; ${ }^{* * *}$ Laís de Carvalho; \\ **Andréa Monte-Alto-Costa; "Ricardo G. Fischer \& *"Luís Cristóvão Porto
}

\begin{abstract}
MILAGRES, D.; RUEFF-BARROSO, C. R.; CARVALHO, S. N.; CARVALHO, L.; MONTE-ALTO-COSTA; FISCHER, R. G. \& PORTO, L. C. Early proliferation of bone marrow mononuclear cells on collagen membrane, bone graft and tooth cementum. Int. J. Morphol., 27(4):1249-1256, 2009.

SUMMARY: The ultimate goal of periodontal therapy is to repair the damaged periodontal supporting tissues, permitting regeneration of the periodontal ligament. However, the cell response, the supportive matrix and the bioactive molecules use have not yet been well established. Bone marrow mononuclear cells were extracted from rat femurs and tibiae and cultured on a cross-linked collagen membrane, bone graft, or molar tooth to compare cell attachment and early proliferation on these materials. Cell attachment was quantified by light microscopy at 24, 48 and $72 \mathrm{~h}$, and cell proliferation was observed under a SEM after $72 \mathrm{~h}$. After $24 \mathrm{~h}$, the number of cells on bone graft was similar to that of the control and more than twice compared to collagen membrane $(q=7.473 \mathrm{p}<0.001)$ and 1.75 times greater than with tooth cementum $(\mathrm{q}=5.613 \mathrm{p}<0.01)$. However, the number of cells close to bone graft decreased in the second day compared to the control. SEM examination revealed a significant decrease in the number of cells that attached and proliferated on tooth and bone graft when compared with membrane. The results showed that bone marrow mesenchymal cells offer great potential for colonize a collagen membrane.
\end{abstract}

KEY WORDS: Stem cells; Collagen membrane; Bone graft; Cementum; Proliferation.

\section{INTRODUCTION}

Human periodontitis is an inflammatory disease affecting the gingiva, periodontal ligament, cementum, and alveolar bone, which affects $\sim 10 \%$ of the adult population and can lead to bone resorption and ultimately tooth loss. Regeneration of the periodontal attachment requires recruitment of osteoblasts, cementoblasts, and periodontal fibroblasts to reconstruct these three distinct tissues (Donzelli et al., 2007; Zhao et al., 2008). Recent research has focused on regeneration of the periodontal ligament (PDL) using tissue engineering. A cell-based approach is one of the most promising alternative therapies for tissue engineering.

Guided tissue regeneration (GTR) is now an essential therapeutic procedure, not only for the treatment of periodontal bone defects but also for bone and peri-implant defects, and for bone augmentation procedures prior to implant placement (Hammerle \& Karring, 1998; Hammerle \& Lang, 2001; Rothamel et al., 2004). Most of GTR techniques, bone graft is often associated with a collagen membrane for the treatment of infra-osseous periodontal lesions (Hasegawa et al., 2006).

The bone marrow mononuclear fraction contains two subsets of stem cells of emerging importance for cell-based therapies: hematopoietic stem cells and mesenchymal stem cells. Bone marrow mesenchymal stem cells offer great potential for regenerating defects in bone, by direct addition of marrow to bone grafts, or by expanding in culture and adding them to the graft (Kadiyala et al., 1997; Chen et al., 2008). Studies demonstrated that different collagen

\footnotetext{
* Department of Periodontics, Rio de Janeiro State University, Rio de Janeiro, Brazil.

** Laboratory of Tissue Repair, Department of Histology and Embryology, Rio de Janeiro State University, Rio de Janeiro, Brazil.

${ }^{* * *}$ Laboratory of Cell Culture, Department of Histology and Embryology, Rio de Janeiro State University, Rio de Janeiro, Brazil.
} 
membranes produce different regenerative response one another (Rothamel et al., 2004). This may be attributed to the influence of different components or structures (Gottlow, 1993; Takata et al., 2001; Rothamel et al.). Osteoblasts-like cells appeared to be incompatible with the collagen membranes, otherwise PDL fibroblasts adhered to most of collagen membranes (Rothamel et al.).

The aim of the present study was to evaluate the biocompatibility of collagen membrane, bone graft, and cementum matrix in promoting the processes of adhesion, and early proliferation of bone marrow mononuclear cells.

\section{MATERIAL AND METHOD}

Cell isolation and culture. This study was approved by the Brazilian Committee for Animal Experimentation (CEA/147/ 2006) for the care and use of laboratory animals. Bone marrow mononuclear cells were extracted from femurs and tibiae of 2-month-old male Wistar rats under strict aseptic conditions. The bones were dissected in the sterile atmosphere of a laminar flow chamber. The epiphysis was removed and the medullar canal was washed with $10 \mathrm{ml}$ of Dulbecco's modified Eagle's medium (DMEM) using a syringe. The medium containing the extracted cells was directed into a Falcon tube and the cells were suspended, homogenized, and centrifuged at 1500 RPM for 10 minutes. The pellet was suspended in 5 $\mathrm{ml}$ of DMEM, gently poured into $5 \mathrm{ml}$ of Ficoll-Histopaque 1077 (Sigma-Aldrich, St Luis, MO, USA), and centrifuged at 2000 RPM for 30 minutes. The floating ring was collected, washed three times in DMEM, and centrifuged at 1500 RPM for 10 minutes. Cells were suspended in $1 \mathrm{ml}$ of DMEM with $20 \%$ of fetal bovine serum with $1 \%$ penicillin/ streptomycin/ gentamicin and counted in a Neubauer chamber. Eight x106 cells/ $\mathrm{ml}$ were incubated in collagen-coated culture dishes and 24-well plates containing a thin porous microfibrillar bovine type I cross-linked collagen membrane, CollaTape $\AA$ (Integra LifeSciences Corporation, Plainsboro, NJ, USA), Extra Graft XG-13® (Silvestre Labs Química e Farmacêutica LTDA, RJ, Brazil) bone graft, a rat molar tooth or alone (Control). Extra Graft $\mathrm{XG}-13 \AA$ is a biomaterial composed of sintered $\left(1100^{\circ} \mathrm{C}\right)$ and powdered hydroxyapatite (HA) and type I collagen (Coll), both of bovine origin, designed for osteoconductive and osteoinductive scaffolds (Rodrigues et al., 2003). Coll/HA proportions were $1 / 2.6$ and $1 / 1$ (wet weight), and particles sizes varied from 200 to $400 \mathrm{~mm}$. Vv (volume density) and $\mathrm{Sv}$ (surface density) of the HA particles in the composite ranged from $0.48+/-0.06$ to $0.55+/-0.02$ and $5.090+/-0.545$ to $6.366+/-0.289 \mathrm{~mm}-1$, respectively. Extra Graft porosity is about $50 \%$ (Rodrigues et al.). Rat molar tooth were extracted and sterilized using an autoclave.
After incubation for $24 \mathrm{~h}, 48 \mathrm{~h}$ and $72 \mathrm{~h}$, the specimens were gently washed with phosphate-buffered saline to remove cells not attached to the surface and fixed with $4 \%$ paraformaldehyde for $60 \mathrm{~min}$. Cells grown on collagen membrane were stained with hematoxylin for observation under a light microscope. Specimens were also sputter-coated with gold for SEM observation (Scanning Microscope LEO1450VP, Zeiss, Germany).

Microscopic analysis. During incubation for $24 \mathrm{~h}, 48 \mathrm{~h}$ and $72 \mathrm{~h}$, bone marrow mononuclear cells were analyzed under an inverted microscope. Five fields (objective: 10x) from each triplicate were chosen near the border of the membrane, bone graft, tooth and randomly in the control and photographed. The cells were counted in a $184 \mathrm{~mm}^{2}$ corresponding surface on the photographs and expressed as $104 \mathrm{cell} / \mathrm{mm}^{2} \pm \mathrm{SEM}$. All experiments were performed in triplicate and repeated twice and evaluation was done by two observers (DM and SC) independently. Cells counts were compared among the different biomaterial present in the culture using a Anova test followed by a Tukey-Kramer test to determine differences them with Instat 3.01 (GraphPad Software Inc., CA, USA). After 72h, coverslips from 24well plates were stained by Romanowsky method (modified Wright's stain) with the hematological staining kit Panotico Rapido (Laborclin, PR, Brazil).

At SEM observation (Scanning Microscope LEO1450VP, Zeiss, Germany), five fields (x 400 enlargement) and 10 fields (x 1000 enlargement) were observed randomly at the materials. Collagen membrane was also scanned at the border and in the middle. Cell morphology was defined as rounded or spindle or flat (adhered) and the number of cells was also semiquantitative evaluated based in the observation of the number of cells found in 10 fields.

\section{RESULTS}

Cell culture. Cells were observed daily, compared to their initial morphology and counted (Table I). After the first 24h, the number of cells cultivated with bone graft was similar to control and more than twice compared to collagen membrane $(q=7.473 p<0.001)$ and 1.75 times greater than in cultures with tooth fragment with cementum $(q=5.613 p<0.01)$. The number of cells close to the biomaterial decreased in the second day of culture compared to the control and we observed an increased in the cells close to the tooth cementum after $72 \mathrm{~h}$, but this was heterogeneous and not statistically different from the other conditions, including the control with less cells, however cells were also observed inside collagen membrane surface due to its translucence. 
MILAGRES, D.; RUEFF-BARROSO, C. R.; CARVALHO, S. N.; CARVALHO, L.; MONTE-ALTO-COSTA, A.; FISCHER, R. G. \& PORTO, L. C. Early proliferation of bone marrow mononuclear cells on collagen membrane, bone graft and tooth cementum. Int. J. Morphol., 27(4):1249-1256, 2009.

Table I. Cell number 104/mm² (mean \pm SEM) after 24, 48 and $72 \mathrm{~h}$ of culture of mononuclear bone marrow cells with tooth, bone graft and collagen membrane. ANOVA: Tukey-Kramer Multiple Comparisons test: *p $<0.05, * * \mathrm{p}<0.01$, $* * * \mathrm{p}<0.001$. SEM - standard error of mean of triplicate essays (cells were counted in a 5 fields of $184 \mathrm{~mm}^{2}$ ).

\begin{tabular}{lcccc}
\hline Time & Culture Dish (control) & Tooth Cementum & Bone Graft & Collagen Membrane \\
\hline $24 \mathrm{~h}$ & $53,9 \pm 8,8$ & $25,2 \pm 3^{* *}$ & $44,1 \pm 3,1$ & $19 \pm 1,6^{* * *}$ \\
$48 \mathrm{~h}$ & $39,2 \pm 8,8$ & $20,4 \pm 2,8$ & $19,1 \pm 2,7$ & $13,6 \pm 1,9^{*}$ \\
$72 \mathrm{~h}$ & $12,2 \pm 1,5$ & $31,5 \pm 5,4$ & $19,7 \pm 4,4$ & $16,9 \pm 2,1$ \\
\hline
\end{tabular}
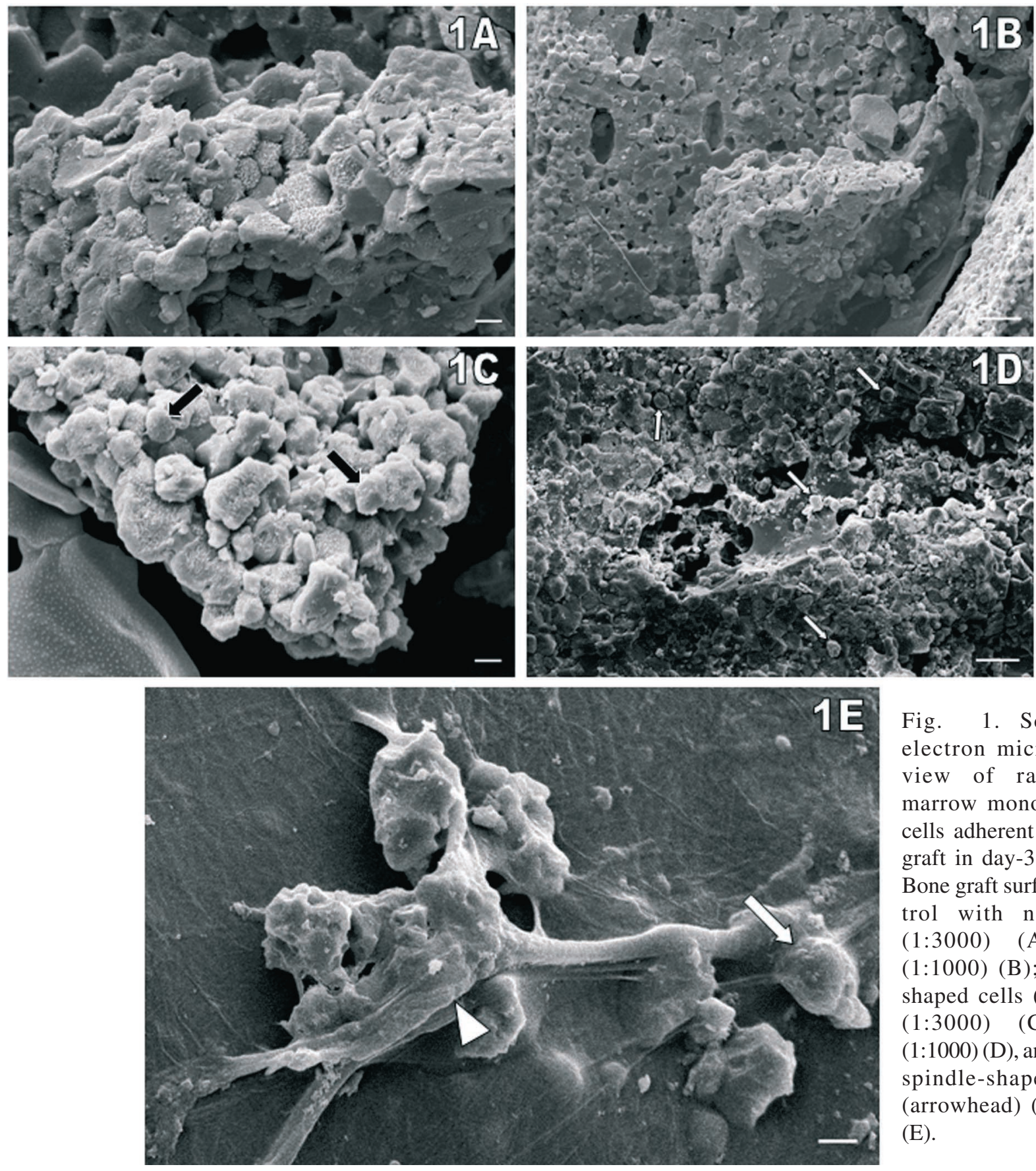

Fig. $\quad$ 1. Scanning electron microscope view of rat bone marrow mononuclear cells adherent to bone graft in day-3 culture. Bone graft surface control with no cells $(1: 3000) \quad(\mathrm{A})$ and (1:1000) (B); roundshaped cells (arrows) $(1: 3000) \quad$ (C) and (1:1000) (D), and scarce spindle-shaped cells (arrowhead) (1:3000) (E). 

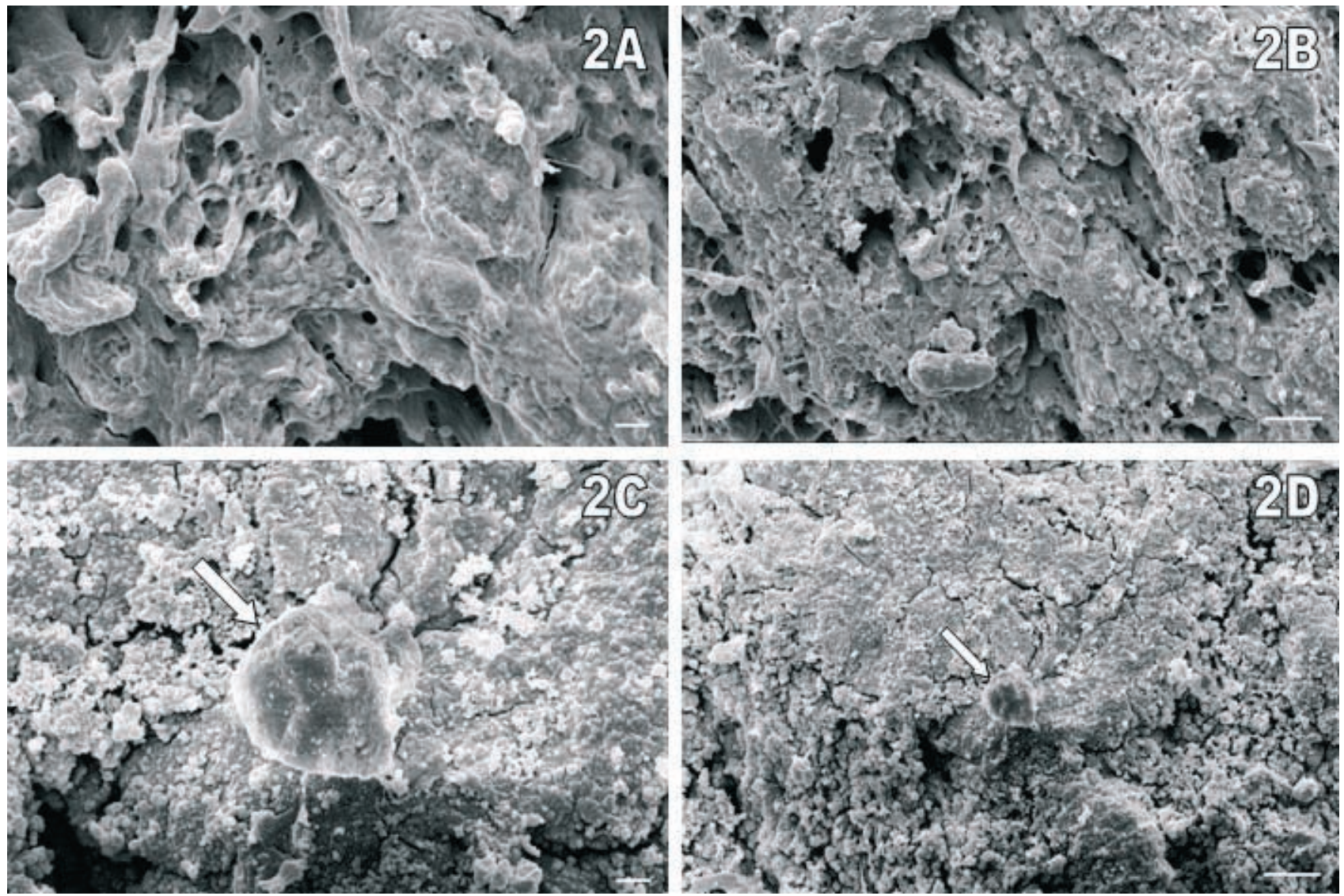

Fig. 2. Scanning electron microscope view of rat bone marrow mononuclear cells adherent to tooth cementum in day-3 culture. Cementum surface control (1:3000) (A) and (1:1000) (B); scarce round-shaped cells (arrows) (1:3000) (C) and (1:1000) (D).

Cell morphology. After $72 \mathrm{~h}$, the control group exhibited fibroblast-like mesenchymal cells with membrane extensions, lymphocytes, monocytes and many macrophages. SEM examination revealed a significant decrease in the number of bone marrow mononuclear cells that attached and proliferated on tooth and bone graft when compared with collagen membrane.

Cells with different morphology grown on bone graft (Fig. 1) and tooth cementum (Fig. 2) when compared with collagen membrane. Most of the cells in bone graft and tooth cementum were round-shaped, whereas in collagen membrane they had spindle-shaped appearance like the mesenchymal lineage or round-shaped similar to hematopoietic cells; and even an endothelial coverage could be observed in border and also in the center of collagen membrane, with cells in close contact displaying membrane extensions (Fig. 3).

\section{DISCUSSION}

We compared the morphological aspect and the early proliferation of these cells in different biomaterials such as collagen membrane, bone graft, and cementum. Bone marrow mononuclear cells display great affinity for collagen membranes, which appear to be more advantageous over bone grafts for adherence and proliferation of these cells. Bone marrow mesenchymal and hematopoietic cells exhibit differentiated morphology after $72 \mathrm{~h}$ in culture. In a recent review, bone marrow mesenchymal cells were considered better seeding cells than PDL cells in periodontal tissue engineering for their multilineage potential. Zhao et al. suggested that the regeneration of the periodontal tissues is dependent on four critical elements: cells, scaffold, appropriate signaling molecules and blood supply. Our study showed round shaped (hematopoietic) cells associated with collagen membrane tissue. However, the presence of these cells in 

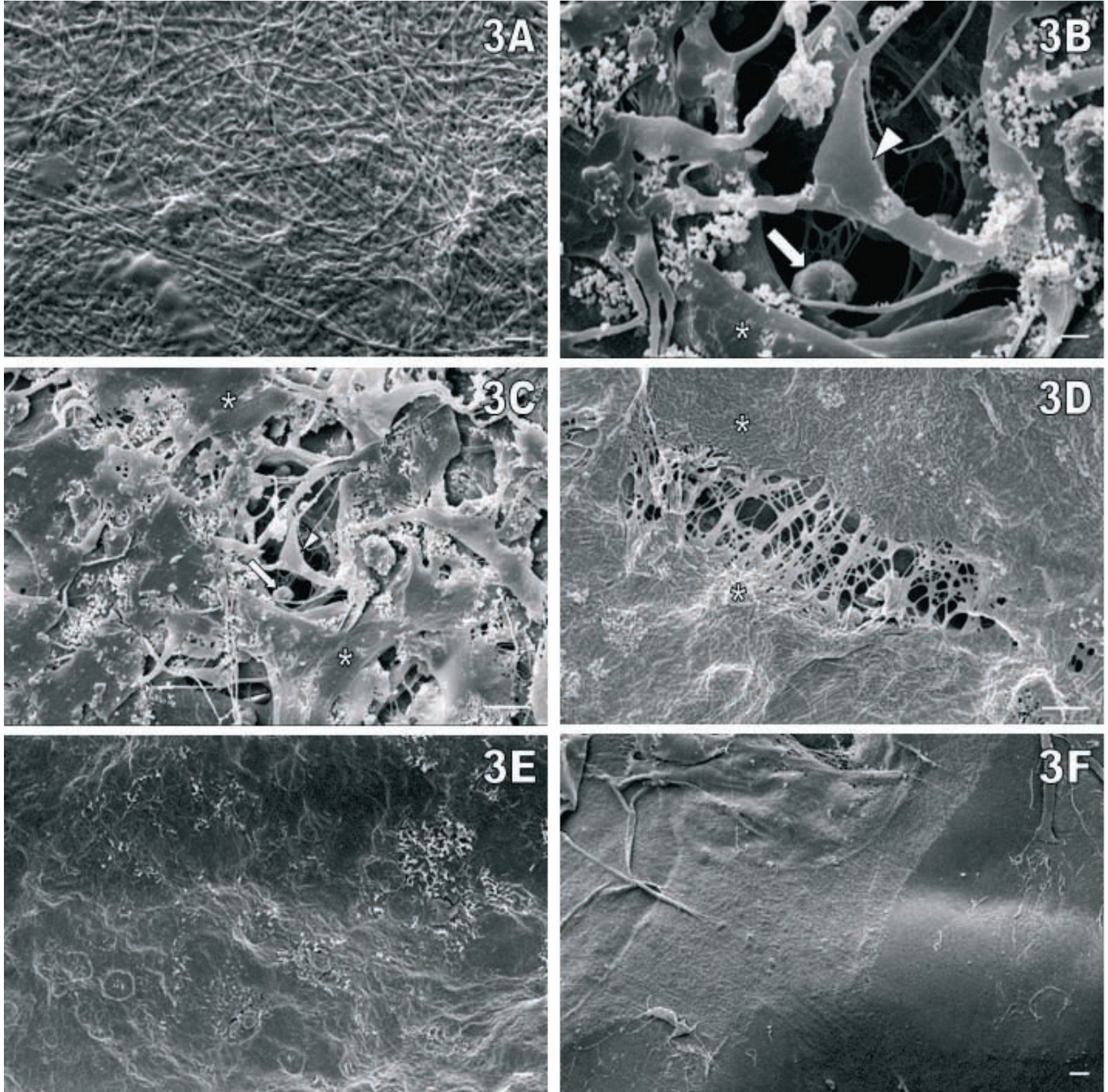

Fig. 3. Scanning electron microscope view of rat bone marrow mononuclear cells adherent to collagen membrane in day-3 culture. Collagen membrane surface control with no cells (1:3000) (A); spindle-shaped (mesenchymal) cells (arrowheads), round-shaped (hematopoietic) cells (arrows), and initial epithelial coverage (asterisks) (1:3000) (B) and (1:1000) (C); advanced degree of epithelization above lamina propria (asterisks) (1:1000) (D); full epithelization observed in collagen membrane borders (1:400) (E); to be compared with membrane surface control (1:400) (F).

culture to support angiogenesis is not well defined. Cells of the hematopoietic lineage are mobilized and then entrapped in peripheral tissues, where they function as accessory cells that may promote the sprouting of resident endothelial cells by releasing angiogenic signals, moreover these cells can also play major roles in tumor angiogenesis (Takakura, 2006). Therefore, manipulating these entrapment signals may offer therapeutic opportunities to stimulate or inhibit angiogenesis (Wang et al., 2002; Takakura; Au et al., 2007).

The number of cells in culture dishes was significantly higher than on CollaTape ${ }^{\circledR}$ collagen membrane. These findings are consistent with previous studies that reported a greater amount of cells attached on culture dishes 
as compared with other bioabsorbable membranes (Takata et al.; Wang et al.; Rothamel et al.). However an increased number of cells were observed in association with Extra Graft XG-13® bone graft when compared with CollaTape ${ }^{\circledR}$ collagen membrane for the first 24 hours. The number of cells in association with Extra Graft XG-13® bone graft decreased in the second day of culture and the SEM observation showed round-shaped cells showing that bone graft appeared to be incompatible with cellular attachment and proliferation. The same rounded cell morphology was observed in another study for BioMend ${ }^{\circledR}$ bovine type I collagen membrane with fibroblasts and osteoblasts cultures (Rothamel et al.). BioMend ${ }^{\circledR}$ enhanced the early osteoblast attachment, since a similar amount of cells was also noted for polylactic and polyglycolic membranes. However, they noted that on BioMend ${ }^{\circledR}$, the cells did not proliferate with time. They attributed to the influence of different components or structures noted in BioMend ${ }^{\circledR}$ like cross-linking with glutaraldehyde that could be a possible explanation for the decreased biocompatibility of this collagen membrane (Rothamel et al.).

However, in another study with Extra Graft XG-13®, the authors deposited human osteoblast cells on bone graft surface. They observed that cells were sparse after 4 days of seeding with the concentration used $\left(7 \times 10^{4}\right.$ cells $\left./ \mathrm{ml}\right)$. Polygonal cells were seen only after 11 days when the cell proliferation, adhesion and spreading were more intense (Rodrigues et al.). Proliferation of bone marrow stem cells may be have a lag phase or be detected in vitro studies with longer than 3 days. It seems that differences in HA exposure observed on different composite surfaces can affect the morphology of attached cells (Rizzi et al., 2001). In our study, althought Extra Graft XG-13® initially attracted a great number of cells it appeared to be not so effective for cellular attachment and proliferation, as with 3 days cells were found most in a round shape, as also in tooth cementum. Further studies are necessary to disclose if bone marrow cells would proliferate on Extra Graft XG-13® after 11 days of experiment.

Membrane scaffolds with osteogenic supplements improve cell differentiation and mineral deposition (Donzelli et al., 2007). But when HA increased to $4 \%$, the porosity and the pore size decreased because parts of the original pores in the scaffolds were occupied by the HA particles. This may be a rational reason for attempts of using $1 \% \mathrm{HA} /$ chitosan scaffold in the regeneration of periodontal tissues (Zhang et al., 2007). This also could explain our results observed with Extra Graft XG-13®.

The number of cells in association with tooth cementum was also significantly lower than on Extra Graft XG-13® bone graft. However these cells were round-shaped such as with bone graft. Another study showed that cementum granules sterilized into 2.5-megarad gamma irradiation cultured with fibronectin induce PDL cells for initial attachment, and cementum has provided evidence that these materials stimulate mineralized-tissue formation (Deveciog $`$ lu et al., 2004) and better results could be achieved using enamel matrix proteins (Cochran et al., 2003) or growth factors (Nevins et al., 2003).

Cell morphology can be regarded as an indicator of the affinity of the cells to a substratum (Trylovich et al., 1992; Takata et al.; Rothamel et al.) related to the proliferation rate (Archer et al.; Rothamel et al.) and migration (Burridge et al., 1987). Scaffolds seem to act as a physical support structure and insoluble regulator of cell activity and differentiation (Könönen et al., 1992; Harley et al., 2007). In our study, bone marrow cells in collagen membrane had spindle-shaped appearance like the mesenchymal lineage or round-shaped similar to hematopoietic cells. Our findings confirm that collagen and chondroitin-4-sulphate are the most suitable biomaterial to stimulate both cellular proliferation and extracellular macromolecule accumulation (Locci et al., 1997; Takata et al.). However, it may be assumed that many tested collagen membranes limit or even inhibit the attachment and proliferation of both fibroblasts and osteoblasts (Takata et al.; Wang et al.; Rothamel et al.). The presence of connective tissue cells on the inner surface of the retrieved membrane is one of the factors that may promote periodontal tissue regeneration (Machtei et al., 1994).

In spite of Extra Graft XG-13® and tooth cementum, a great number of cells from different morphology were observed in collagen membrane. The bone marrow stem cells adherent on CollaTape ${ }^{\circledR}$ collagen membrane were flattened and differentiated, whereas bone marrow stem cells adherent on Extra Graft XG-13® were more round in shape, seem to indicate that CollaTape ${ }^{\circledR}$ offer surface conditions more favorable to the attachment and proliferation of these cells than Extra Graft XG-13® or rat tooth cementum. Furthermore, rat tooth cementum seemed to be incompatible with bone marrow cell attachment and proliferation.

This study showed that bone marrow mesenchymal cells offer great potential for colonize a collagen membrane. It was also shown the advantages of CollaTape ${ }^{\circledR}$ collagen membrane over the Extra Graft XG-13® for adherence and proliferation of mononuclear bone marrow cells, allowing the differentiation of these cells into flattened and adherent cells.

ACKNOWLEDGEMENTS. To Prof. Helio Rodrigues Sampaio Filho from Faculty of Odontology and Alan Cesar Nunes de Moraes from Laboratory of Electron Microscopy Prof. Luiz Henrique Monteiro Leal both from State University of Rio de Janeiro. 
MILAGRES, D.; RUEFF-BARROSO, C. R.; CARVALHO, S. N.; CARVALHO, L.; MONTE-ALTO-COSTA; FISCHER, R. G. \& PORTO, L. C. Proliferación temprana de células mononucleares de médula ósea sobre membrana de colágeno, injerto óseo y cemento dentario. Int. J. Morphol., 27(4):1249-1256, 2009.

RESUMEN: El objetivo último de la terapia periodontal es reparar el daño tejidos periodontales de soporte, permitiendo la regeneración del ligamento periodontal. Sin embargo, la respuesta de la célula, la matriz de apoyo y las moléculas bioactivas aún no han sido bien establecidas. Células mononucleares de la médula ósea se extrajeron del fémur y fibula de rata, y fueron cultivadas sobre un reticulado de membrana de colágeno, de injerto de hueso o de un diente molar para comparar la adhesión celular y la proliferación temprana sobre estos materiales. La adhesión celular fue cuantificada por microscopía de luz a las 24, 48 y $72 \mathrm{~h}$, y la proliferación celular fue observada bajo MEB después de 72h. Después de 24 horas, el número de células sobre el injerto de hueso fue similar a la del control y más del doble en comparación con la membrana de colágeno ( $q=7,473 \mathrm{p}<0,001)$ y 1,75 veces mayor que con el cemento dental $(q=5,613$ p $<0,01)$. Sin embargo, el número de células cerca del injerto óseo disminuyó el segundo día en comparación con el control. El examen al MEB reveló una disminución significativa en el número de células que se unen y proliferan sobre los dientes y el injerto óseo en comparación con la membrana. Los resultados mostraron que las células mesenquimales de la médula ósea tienen un gran potencial para colonizar la membrana de colágeno.

PALABRAS CLAVE: Células madre; Membrana de colágeno; Injerto óseo; Cemento; Proliferación.

\section{REFERENCES}

Archer, C. W.; Rooney, P. \& Wolpert, L. Cell shape and cartilage differentiation of early chick limb bud cells in culture. Cell Differ., 11(4):245-51, 1982.

Au, A.; Boehm, C. A.; Mayes, A. M.; Muschler, G. F. \& Griffith, L. G. Formation of osteogenic colonies on welldefined adhesion peptides by freshly isolated human marrow cells. Biomaterials, 28(10):1847-61, 2007.

Burridge, K.; Molony, L. \& Kelly, T. Adhesion plaques: sites of transmembrane interaction between the extracellular matrix and the actin cytoskeleton. J. Cell Sci. Suppl., 8:211-29, 1987.

Chen, Y. L.; Chen, P. K.; Jeng, L. B.; Huang, C. S.; Yang, L. C.; Chung, H. Y. \& Chang, S. C. Periodontal regeneration using ex vivo autologous stem cells engineered to express the BMP-2 gene: an alternative to alveolaplasty. Gene Ther., 15(22):1469-77, 2008.

Cochran, D. L.; King, G. N.; Schoolfield, J.; Velasquez-Plata, D.; Mellonig, J. T. \& Jones, A. The effect of enamel matrix proteins on periodontal regeneration as determined by histological analyses. J. Periodontol., 74(7):1043-55, 2003.

Deveciog $\$ lu, D.; Tözüm, T. F.; Sengün, D. \& Nohutcu, R. M. Biomaterials in periodontal regenerative surgery: effects of cryopreserved bone, commercially available coral, demineralized freeze-dried dentin, and cementum on periodontal ligament fibroblasts and osteoblasts. $J$. Biomater. Appl., 19(2):107-20, 2004.
Donzelli, E.; Salvadè, A.; Mimo, P.; Viganò, M.; Morrone, M.; Papagna, R.; Carini, F.; Zaopo, A.; Miloso, M.; Baldoni, M. \& Tredici, G. Mesenchymal stem cells cultured on a collagen scaffold: In vitro osteogenic differentiation. Arch. Oral Biol., 52(1):64-73, 2007.

Gottlow, J. Guided tissue regeneration using bioresorbable and non-resorbable devices: initial healing and long-term results. J. Periodontol., 64(11):1157-65, 1993.

Hammerle, C. H. \& Karring, T. Guided bone regeneration at oral implant sites. Periodontol., 2000, 17:151-75, 1998.

Hammerle, C. H. \& Lang, N. P. Single stage surgery combining transmucosal implant placement with guided bone regeneration and bioresorbable materials. Clin. Oral Implants Res., 12(1):9-18, 2001.

Harley, B. A.; Leung, J. H.; Silva, E. C. \& Gibson, L. J. Mechanical characterization of collagenglycosaminoglycan scaffolds. Acta Biomater., 3(4):46374, 2007.

Hasegawa, N.; Kawaguchi, H.; Hirachi, A.; Takeda, K.; Mizuno, N.; Nishimura, M.; Koike, C.; Tsuji, K., Iba, H.; Kato, Y. \& Kurihara, H. Behavior of transplanted bone marrow-derived mesenchymal stem cells in periodontal defects. J. Periodontol., 77(6):1003-7, 2006.

Kadiyala, S.; Young, R. G.; Thiede, M. A. \& Bruder, S. P. Culture expanded canine mesenchymal stem cells 
possess osteochondrogenic potential in vivo and in vitro. Cell Transplant., 6(2):125-34, 1997.

Könönen, M.; Hormia, M.; Kivilahti, J.; Hautaniemi, J. \& Thesleff, I. Effect of surface processing on the attachment, orientation, and proliferation of human gingival fibroblasts on titanium. J. Biomed. Mater. Res., 26(10):1325-41, 1992.

Locci, P.; Calvitti, M.; Belcastro, S.; Pugliese, M.; Guerra, M.; Marinucci, L.; Staffolani, N. \& Becchetti, E. Phenotype expression of gingival fibroblasts cultured on membranes used in guided tissue regeneration. $J$. Periodontol., 68(9):857-63, 1997.

Machtei, E. E.; Cho, M. I.; Dunford, R.; Norderyd, J.; Zambon, J. J. \& Genco, R. J. Clinical, microbiological, and histological factors which influence the success of regenerative periodontal therapy. J. Periodontol., 65(2):154-61, 1994.

Nevins, M.; Camelo, M.; Nevins, M. L.; Schenk, R. K. \& Lynch, S. E. Periodontal regeneration in humans using recombinant human platelet-derived growth factor-BB (rhPDGF-BB) and allogenic bone. J. Periodontol., 74(9):1282-92, 2003.

Rizzi, S. C.; Heath, D. J.; Coombes, A. G.; Bock, N.; Textor, M. \& Downes, S. Biodegradable polymer/ hydroxyapatite composites: surface analysis and initial attachment of human osteoblasts. J. Biomed. Mater. Res., 55(4):475-86, 2001.

Rodrigues, C. V.; Serricella, P.; Linhares, A. B.; Guerdes, R. M.; Borojevic, R.; Rossi, M. A.; Duarte, M. E. \& Farina, M. Characterization of a bovine collagen-hydroxyapatite composite scaffold for bone tissue engineering. Biomaterials, 24(27):4987-97, 2003.

Rothamel, D.; Schwarz, F.; Sculean, A.; Herten, M.; Scherbaum, W. \& Becker, J. Biocompatibility of various collagen membranes in cultures of human PDL fibroblasts and human osteoblast-like cells. Clin. Oral Implants Res., 15(4):443-9, 2004.

Takakura, N. Role of hematopoietic lineage cells as accessory components in blood vessel formation. Cancer Sci., 97(7):568-74, 2006.

Takata, T.; Wang, H. L. \& Miyauchi, M. Attachment, proliferation and differentiation of periodontal ligament cells on various guided tissue regeneration membranes. J. Periodontal Res., 36(5):322-7, 2001.
Trylovich, D. J.; Cobb, C. M.; Pippin, D. J.; Spencer, P. \& Killoy, W. J. The effects of the Nd:YAG laser on in vitro fibroblast attachment to endotoxin-treated root surfaces. J. Periodontol., 63(7):626-32, 1992.

Wang, H. L.; Miyauchi, M. \& Takata, T. Initial attachment of osteoblasts to various guided bone regeneration membranes: an in vitro study. J. Periodontal Res., 37(5):340-4, 2002.

Zhang, Y. F.; Cheng, X. R.; Chen, Y.; Shi, B.; Chen, X. H.; $\mathrm{Xu}, \quad \mathrm{D} . \mathrm{X} . \quad \& \mathrm{Ke}, \mathrm{J}$. Three-dimensional nanohydroxyapatite/chitosan scaffolds as potential tissue engineered periodontal tissue. J. Biomater. Appl., 21(4):333-49, 2007.

Zhao, Q.; Gong, P.; Tan, Z. \& Yang, X. Differentiation control of transplanted mesenchymal stem cells (MSCs): A new possible strategy to promote periodontal regeneration. Med. Hypotheses, 70(5):944-7, 2008.

Correspondence to:

Luis Cristóvão Porto, MD, ScD

Laboratório de Reparo Tecidual

Departamento de Histologia e Embriologia

Universidade do Estado do Rio de Janeiro

Av Prof Manuel de Abreu $4443^{\circ}$. Andar 20551-170

Rio de Janeiro, BRAZIL

Tel/fax 552125876509

Email: Icporto@uerj.br

Received: 02-09-2009

Accepted: 03-10-2009 